\title{
MENINGKATKAN KESADARAN MASYARAKAT CIWARINGIN TANAH SEWA TENTANG PENTINGNYA PROTOKOL KESEHATAN DI MASA PANDEMI COVID-19
}

DOI: https://doi.org/10.33024/jkpm.v4i5.4123

Ade Saputra Nasution ${ }^{1 *}$, Khrisna Noor Oktalaksana², Nicki Amalia ${ }^{3}$, Nita Ratu Azizah $^{4}$, Syifaur Rahmah ${ }^{5}$, Wisma Sari ${ }^{6}$

${ }^{1-6}$ Kesehatan Masyarakat, Fakultas IImu Kesehatan Universitas Ibn Khaldun

Disubmit: 24 Maret 2021 Diterima: 06 Mei $2021 \quad$ Diterbitkan: 30 September 2021

Email korespondensi: adenasution@uika-bogor.ac.id

\begin{abstract}
ABSTRAK
Jumlah insidensi meninggal akibat covid-19 terus meningkat di dunia dan negara berkembang seperti Indonesia. Terhitung bulan Januari-Februari 2021 terdapat 82 kasus terkonfirmasi positif COVID-19 di Kelurahan Cibogor wilayah kerja Puskesmas Bogor Tengah. Sebanyak 16 kasus dari 82 kasus terdapat di wilayah RW 01 Ciwaringin Tanah Sewa Kelurahan Cibogor. Maka penerapan protokol kesehatan menjadi prioritas utama dalam menurunkan maupun menekan penyebaran covid-19. Tujuan serangkaian kegiatan pengabdian ini, diharapkan dapat meningkatkan kesadaran, pengetahuan, kemampuan, pemahaman dan penerapan protokol kesehatan dalam kehidupan pada masa pandemi dan dapat mencegah penyebaran covid-19 di RW 01 Ciwaringin Tanah Sewa. Adapun serangkaian kegiatan yang dilakukan berupa penyuluhan protokol kesehatan secara door to door, lomba CTPS dan lomba menghias masker, dimana kegiatan ini menggunakan media poster dan peralatan lomba. Setelah dilakukan serangkian kegiatan terdapat peningkatan kesadaran, pengetahuan, kemampuan dan pemahaman masyarakat tentang menjalankan hidup di masa pandemi dengan protokol kesehatan.
\end{abstract}

Kata Kunci : Protokol kesehatan, penyuluhan, CTPS, masker

\section{ABSTRACT}

The number of deaths due to covid-19 continues to increase in the world and developing countries such as Indonesia. As of January-February 2021, there were 82 confirmed positive cases of COVID-19 in Cibogor Village, the working area of the Central Bogor Community Health Center. As many as 16 of the 82 cases were in the RW 01 Ciwaringin Tanah Sewa area, Cibogor Village. So the implementation of health protocols is a top priority in reducing and suppressing the spread of covid-19. The purpose of this series of service activities is expected to increase awareness, knowledge, ability, understanding, and application of health protocols in life during the pandemic and can prevent the spread of covid19 in RW 01 Ciwaringin Tanah Sewa. There were a series of activities carried out in the form of house-to-house health protocol counseling, hand washing competitions with soap and masks decorating competitions, where these activities used posters and competition equipment. After a series of activities 
were carried out, there was an increase in the awareness, knowledge, abilities and understanding of the community about living in a pandemic period with health protocols.

Keywords: Health protocol, counseling, washing hands with soap, masks

\section{PENDAHULUAN}

World Health Oragnization (WHO) menyatakan bencana yang berupa wabah penyakit atau pandemi penyakit menular Corona Virus Disease - 19 (COVID-19) yang disebabkan oleh virus SARS-COV 2 atau Virus Corona. Infeksi covid-19 dapat menyebabkan kesakitan bahkan lebih fatal dapat menyebabkan kematian. Untuk menangani pandemi covid-19 perlu dilakukan langkah-langkah penanggulangan termasuk melibatkan seluruh komponen masyarakat (Sari 2020; Shalahuddin et al. 2021).

Data dari Puskesmas Bogor Tengah, per bulan Januari-Februari 2021 terdapat 82 kasus yang terkonfirmasi positif COVID-19. Kasus tersebut tersebar di kelurahan yang menjadi wilayah kerja Puskesmas Bogor Tengah yaitu Kelurahan Cibogor. Total kasus sebanyak 82 kasus yang terdapat di Kelurahan Cibogor tersebut, sebanyak 16 kasus terdapat di wilayah RW 01 Ciwaringin Tanah Sewa Kelurahan Cibogor (Puskesmas Bogor Tengah, 2021).

Pencegahan penularan covid-19 di masyarakat perlu ditingkatkan mengenai pengetahuan serta kepatuhan dalam penggunaan masker yang berperan penting sebagai preventif atau kejadian berulang dalam penularan covid-19. Masyarakat harus mengenal, mempelajari, dan memahami segala aspek dari penyakit covid19 termasuk penyebab, gejala serta tanda, pencetus maupun penatalaksanaannya. Pengetahuan yang dimiliki oleh masyarakat berkaitan erat pada sebuah keputusan yang akan diambil, karena seseorang dalam menetapkan pilihan melalui landasan dari sebuah pengetahuan yang dimilikinya (Fernalia et al., 2021).

Pengetahuan tentang cara pemeliharaan kesehatan serta cara menghindari terjangkitnya sebuah penyakit, dengan sendirinya dapat meningkatkan pengetahuan yang dimiliki oleh masyarakat. Pengetahuan tentang covid-19 merupakan hal yang sangat penting, untuk menghindari peningkatan jumlah kasus. Pengetahuan memiliki peranan penting dalam proses penentuan perilaku karena pengetahuan dapat membentuk kepercayaan dalam hal mempersepsikan kenyataan, sebagai dasar dalam pengambilan keputusan dan penentuan perilaku terhadap suatu objek yang dapat berpengaruh terhadap perilaku (Fasya et al., 2021).

Salah satu langkah dalam penanganan covid-19 yang dianjurkan WHO dan Pemerintah Indonesia adalah penggunakan masker saat berada di luar rumah. Upaya pencegahan dan pengendalian dalam membatasi penyebaran infeksi COVID-19 perlu sebuah upaya yang komprehensif dalam penggunaan masker. Masker dapat berfungsi untuk melindungi orang sehat maupun orang yang sudah terinfeksi sebagai pencegahan penularan kepada orang lain (Armiani et al. 2020; Meri et al. 2020).

Upaya pencegahan covid-19 dapat juga dilakukan dengan penerapan cuci tangan pakai sabun (CTPS) dengan langkah membersihkan tangan, jari jemari menggunakan sabun dan air mengalir. Tangan manusia dapat menjadi agen pembawa kuman dan penyebab patogen dapat berpindah dari dari alam atau 
satu orang kepada orang lain melalui kontak secara tidak langsung atau langsung (Listina et al., 2020).

Dari berbagai alasan tersebut diatas maka penulis tertarik melakukan pengabdian masyarakat dalam meningkatkan pengetahuan, pemahaman serta kesadaran masyarakat mengenai manfaat maupun pentingnya menggunakan masker pada masa pandemi saat di luar rumah dan mencuci tangan setelah melakukan aktivitas, sehingga membentuk sebuah perilaku sehat dengan kesadaran diri yang tinggi guna meningkatkan derajat kesehatan masyarakat yang setinggi-tingginya.

\section{MASALAH}

Alasan penulis memilih tempat kegiatan pengabdian masyarakat di Ciwaringin Tanah Sewa karena masyarakat masih abai dalam menjalankan protokol kesehatan seperti tidak menggunakan masker jika diluar rumah, tidak mencuci tangan setelah melakukan aktifitas dan tidak menjaga jarak satu sama lain sehingga dapat memicu penyebaran covid-19. Hal ini menjadi alasan penulis untuk melakukan peningkatan kesadaran diri masyarakat dalam menjalankan protokol kesehatan khususnya penggunaan masker dan CTPS dalam mencegah penularan covid-19.

Pencegaham merupakan sebuah upaya yang harus dilakukan yaitu dengan menerapkan berbagai kegiatan, seperti melakukan kegiatan penyuluhan masyarakat guna memberikan informasi dan data yang ilmiah pada seluruh lapisan dimasyarakat mengenai wabah covid-19 di Indonesia dan Ciwaringin Tanah Sewa Khususnya. Pemahaman dan pengetahuan yang ilmiah, dapat dipercaya dan akurat akan membantu masyarakat dapat dengan mudah menerapkan arahan dan himbuan pemrintah sehingga menekan penyebaran wabah Covid-19 di Kota Bogor. Atas dasar penjelasan inilah penulis telah melaksanakan kegiatan penyuluhan kesehatan masyarakat guna meningkatkan pemahaman dan pengetahuan masyarakat Ciwaringin Tanah Sewa agar dapat mencegah penyebaran wabah Covid-19.

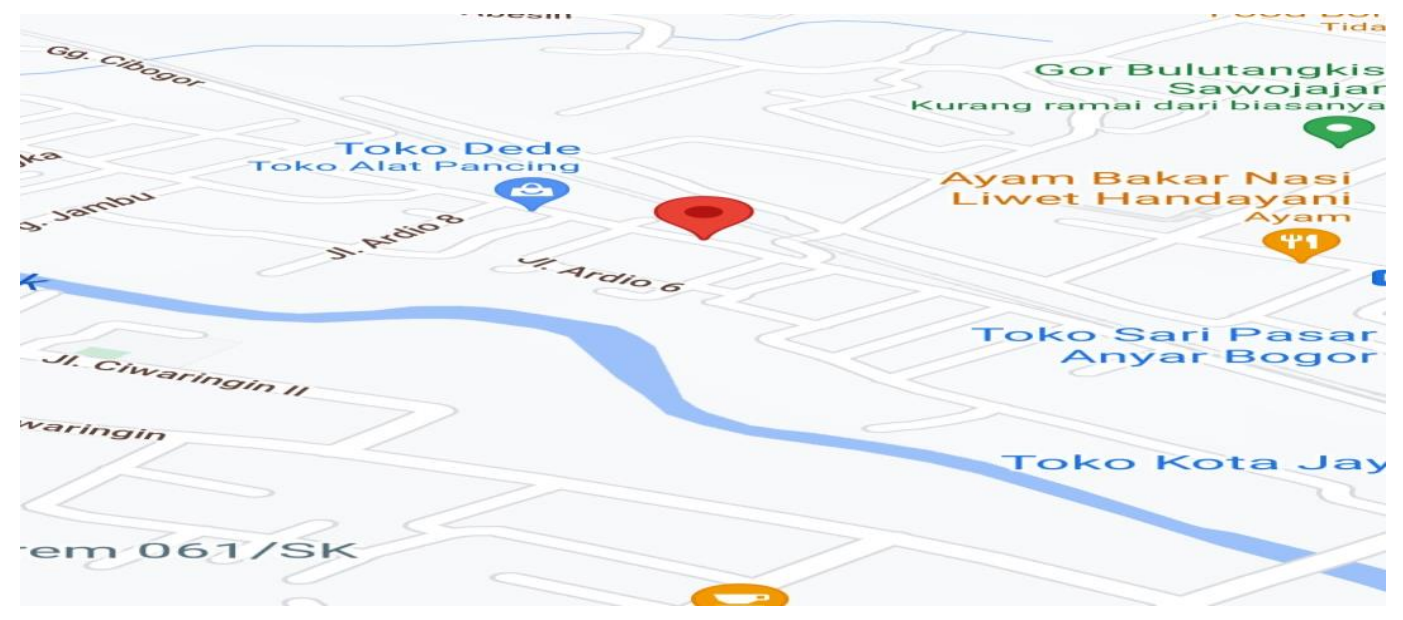

Gambar 2.1 Peta Lokasi Kegiatan Pengbdian Kepada Masyarakat. 


\section{METODE}

a. Tujuan Persiapan

Tahap persiapan dari kegiatan pengabdian masyarakat di wilayah kerja Puskesmas Bogor Tengah yaitu di Ciwaringin Tanah Sewa adalah pembuatan poster untuk penyuluhan protokol kesehatan, persiapan lomba CTPS dan persiapan lomba menghias masker, tempat dan alat-alat lainnya disiapkan.

b. Tahap pelaksanaan

Acara ini dilaksanakan dengan memberitahuan kepada perangkat Desa Ciwaringin Tanah Sewa dan Puskesmas Bogor Tengah agar dapat mengarahkan masyarakat untuk berkumpul. Materi yang disampaikan dalam acara penyuluhan adalah pencegahan covid-19 dengan penerapan protokol kesehatan baik di dalam rumah maupun jika berada di luar rumah. Kegiatan pengabdian masyarakat di Ciwaringin Tanah Sewa dilakukan pada tanggal 20 dan 25 Februari 2021 dengan 3 program kegiatan yaitu penyuluahan protokol kesehatan di masa pandemi, lomba CTPS dan lomba menghias masker

c. Evaluasi

i. Struktur

Kegiatan pertama yaitu penyuluahan protokol kesehatan secara door to door sebanyak 30 rumah warga Ciwaringin Tanah Sewa. Dalam proses penyuluahan protokol kesehatan kepada masyarakat penulis menggunakan poster guna memudahkan masyarakat untuk memahi apa yang disampaikan. Penyampaian bahasa dalam penyuluhan kesehatan sudah komunikatif, menarik, mudah dimengerti oleh masyarakat dan memberikan kesempatan kepada audiensi atau peserta untuk diskusi selama proses penyuluhan berlangsung.

Kegiatan kedua yaitu lomba CTPS yang dihadiri oleh 10 anak-anak, dimulai dari proses penyuluhan supaya anak-anak mengetahui langkah-langkah dan cara mencuci tangan yang baik dan benar, selanjutkan dilakukan lomba CTPS untuk melihat apakah informasi yang sudah disampaikan bisa dipraktikkan secara benar oleh anak-anak.

Kegiatan ketiga yaitu lomba menghias masker yang dihadiri sebanyak 15 anak-anak. Kegiatan ini dimulai dari proses penyuluhan supaya anak-anak mengetahui langkah-langkah dan cara memakai masker baik dan benar, selanjutkan dilakukan lomba menghias masker guna meningkatkan kesadaran, kepedulian anak-anak terhadap pencegahan penyebaran covid19 dan meningkatkan kreatifitas anak-anak dalam menuangkan imajinasi pada kegiatan menggambar masker.

ii. Proses

Pelaksanaan kegiatan pukul 09.00. Sesuai dengan jadwal yang telah direncanakan.

\section{HASIL DAN PEMBAHASAN}

Metode pelaksanaan dalam kegiatan pengabdian kepada masyarakat Ciwaringin Tanah Sewa ini dilaksanakan pada tanggal 20 dan 25 Februari 2021. Pelaksanaan kegiatan pertama yaitu penyuluhan kesehatan secara door to door telah dilakukan kepada 30 rumah warga dan warga RW 01 adanya peningkatan pengetahuan mengenai gejala, tanda maupun pencegahan covid-19 dengan menerapkan protokol kesehatan baik di dalam rumah maupun berada di luar 
rumah. Alat dan media yang digunakan dalam proses penyuluhan adalah poster. Metode yang digunakan adalah ceramah dan tanya jawab.

Pelaksanaan kegiatan kedua yaitu lomba CTPS yang dihadiri 10 anak-anak pada tanggal 20 Februari 2021. Sebelum lomba kegiatan ini dimulai dengan melakukan penyuluhan CTPS yang baik dan benar. Alat dan media yang digunakan dalam proses penyuluhan adalah poster dan peralatan lomba CTPS. Metode yang digunakan adalah ceramah dan tanya jawab atau evaluasidengan mempraktikkan CTPS yang baik dan benar.

Pelaksanaan kegiatan ketiga yaitu lomba menghias masker yang dihadiri sebanyak 15 anak-anak pada tanggal 20 Februari 2021. Sebelum lomba kegiatan ini dimulai dengan melakukan penyuluhan pentingnya penggunaan masker dimasa pandemi. Alat dan media yang digunakan dalam proses penyuluhan adalah poster dan peralatan lomba menghias masker. Metode yang digunakan adalah ceramah dan tanya jawab atau evaluasidengan mempraktikkan memakai masker yang benar dan menghias masker. Berikut gambar pelaksanaan kegiatan:

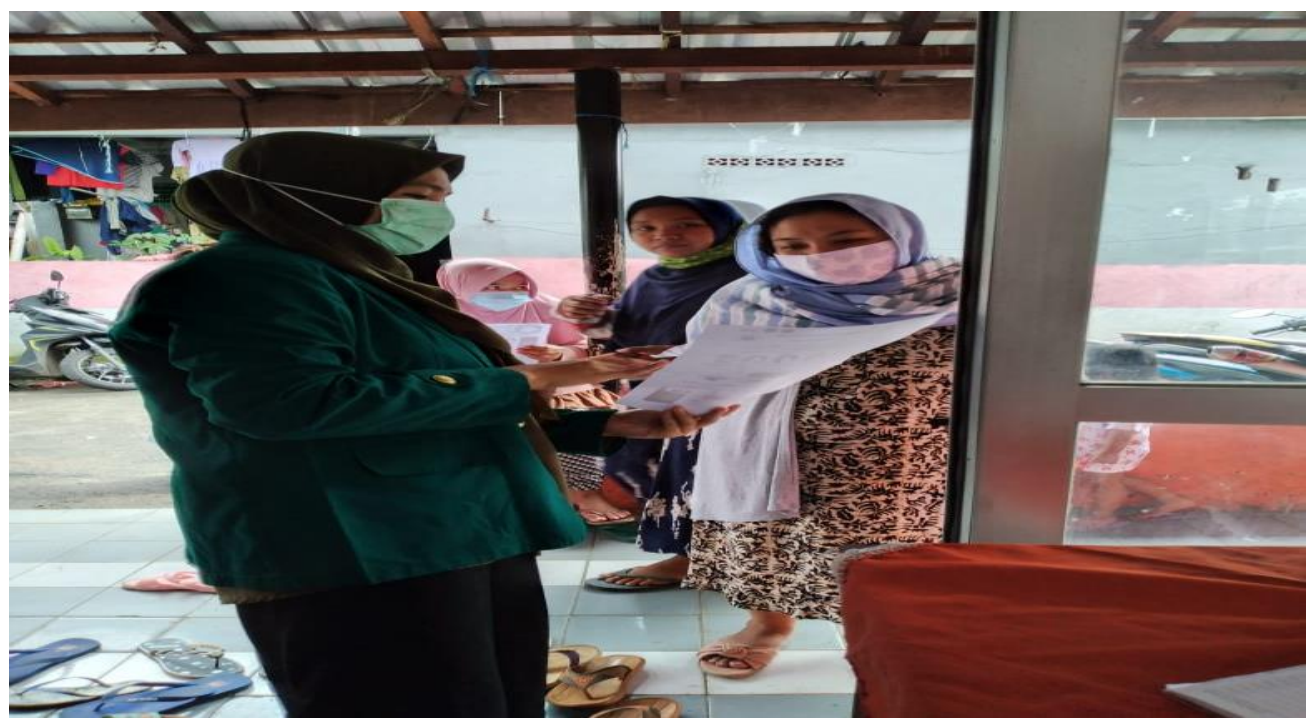

Gambar 2.2 Foto Kegiatan PKM Penyuluahan Door to Door

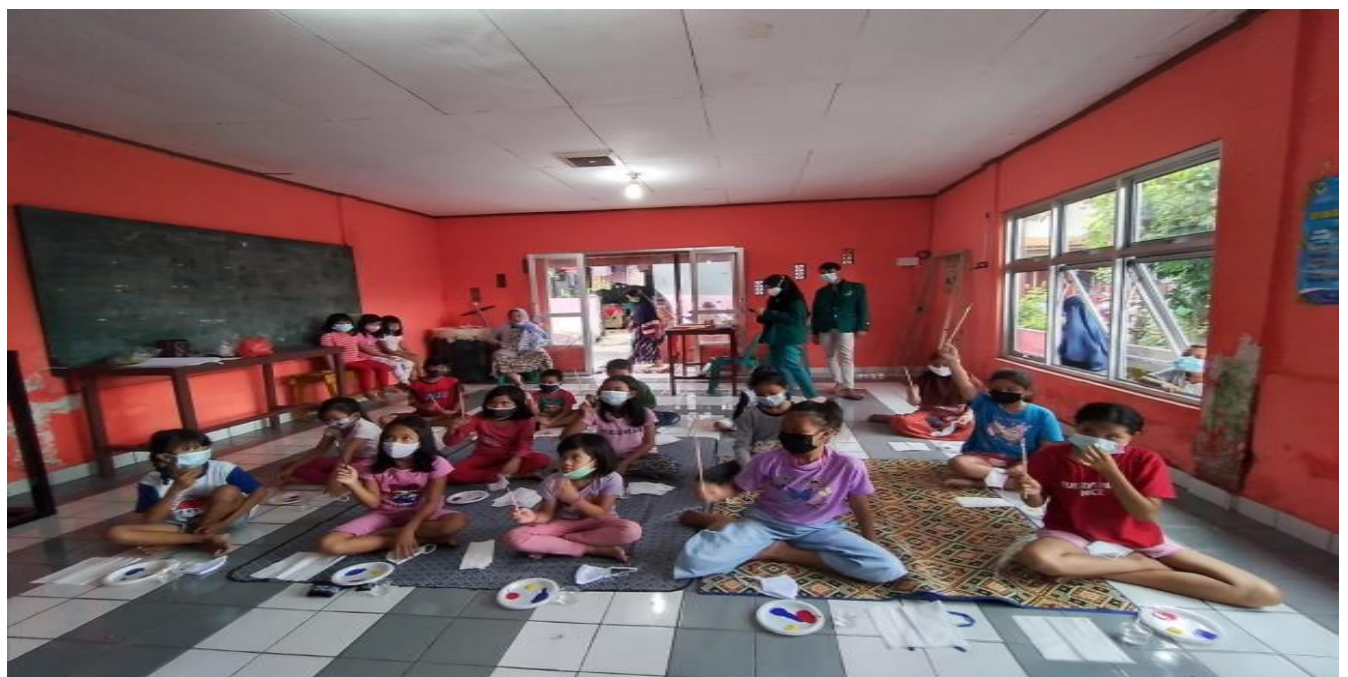


Gambar 2.3 Kegiatan PKM Lomba Menghias Masker

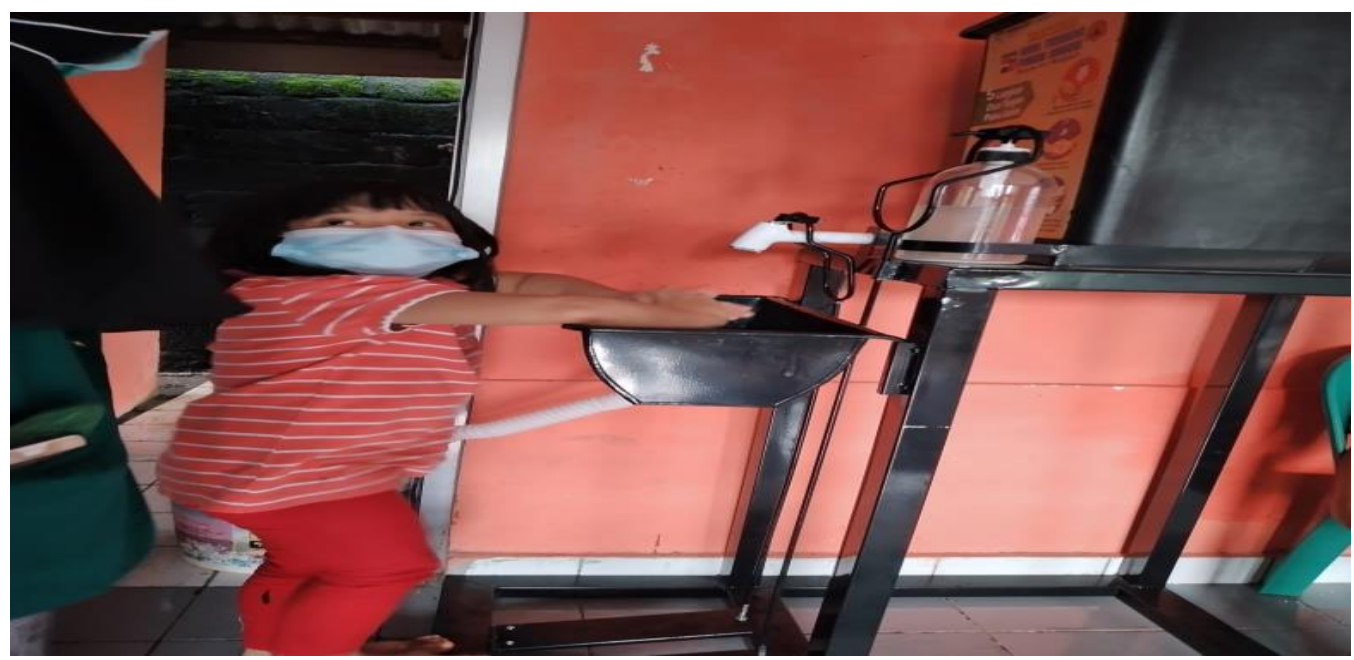

Gambar 2.3 Kegiatan PKM Lomba CTPS

\section{KESIMPULAN}

Kegiatan pengabdian kepada masyarakat khususnya RW 01 Ciwaringin Tanah Sewa yang merupakan wilayah kerja Puskesmas Bogor Tengah pada tanggal 20 dan 25 Februari 2021 telah berjalan dengan baik, lancar dan benar. Masyarakat yang megikuti program kegiatan pengabdian ini sangat antusias, aktif dan dapat bekerja sama. Adapun hasil kegiatan pengabdian masyarakat ini yaitu menignkatnya pengetahuan masyarakat mengenai protokol kesehatan guna mencegah penularan covid-19 seperti penggunaan masker dan CTPS dengan benar.

\section{DAFTAR PUSTAKA}

Armiani, S., Fajri, S. R., Sukri, A., \& Pidiawati, B. Y. (2020). Pelatihan Pembuatan Masker Sebagai Upaya Antisipasi Penyebaran Covid-19 di Desa Anyar Kabupaten Lombok Utara. Jurnal Pengabdian UNDIKMA, 1(1), 22-27. https: //doi.org/10.33394/jpu.v1i1.2550

Fasya, H., Pratama, S. A., Mandala, Z., Nurmalasari, Y., \& Pebrian, U. (2021). Penyuluhan Tentang Protokol Kesehatan Covid -19 Pada Masyarakat Di Puskesmas Sumur Batu Teluk Utara Bandar Lampung. JURNAL KREATIVITAS PENGABDIAN KEPADA MASYARAKAT (PKM), 4(1), 195-199.

Fernalia, Pawiliyah, Rahmawati, I., Juksen, L., Sanisahhuri, \& Syamsu, R. (2021). Sosialisasi Pengunaan Masker Dan Pembagian Masker Kepada Warga Untuk Pencegahan Covid 19 Di Pasar Tradisional Kota Bengkulu. JURNAL KREATIVITAS PENGABDIAN KEPADA MASYARAKAT (PKM), 4(1), 10-17.

Listina, O., Solikhati, D. I. K., \& Fatmah, I. S. (2020). Edukasi Corona Virus Desease 19 (Covid-19) Melalui Penyebaran Poster Kepada Masyarakat Kecamatan Slawi Kabupaten Tegal. JABI: Jurnal Abdimas 
Bhakti Indonesia, 1(2), 10-10. http:/ / ojs.stikesbhamadaslawi.ac.id/index.php/JABI/article/view/ 210

Meri, Khusnul, Suhartati, R., Mardiana, U., \& Nurpalah, R. (2020). Pemberdayaan Masyarakat Dalam Penggunaan Hand Sanitizier dan Masker Sebagai Upaya Preventif Terhadap Covid-19. Bantenese Jurnal Pengabdian Masyarakat, 2(1), 26-33. https: / /doi.org/10.30656/ps2pm.v2i1.2340

Sari, M. K. (2020). Sosialisasi tentang Pencegahan Covid-19 di Kalangan Siswa Sekolah Dasar di SD Minggiran 2 Kecamatan Papar Kabupaten Kediri. Jurnal Karya Abdi, 4(1), 80-83.

Shalahuddin, I., Rosidin, U., Purnama, D., Keperawatan, F., Padjadjaran, U., Garut, K., Keperawatan, F., Padjadjaran, U., Garut, K., Keperawatan, F., Padjadjaran, U., \& Garut, K. (2021). Edukasi Pada Masyarakat Desa Mekarbakti Kecamatana Pamulihan Kabupaten Sumedang Tentang Pentingnya Upaya-UpayamPencegahan Penularan Penyakit Covid-19. JURNAL KREATIVITAS PENGABDIAN KEPADA MASYARAKAT (PKM), 4(1), 1-9. 